\title{
ІДЕНТИФІКАЦІЯ ЧИННИКІВ КОМЕРЦІАЛІЗАЦІЇ ДІЯЛЬНОСТІ НАТУРАЛЬНИХ ГОСПОДАРСТВ В УКРАЇНІ
}

\author{
Коблянська Інна Ігорівна \\ кандидат економічних наук. доцент \\ Сумський національний аграрний університет (м.Суми, Україна) \\ ORCID: 0000-0002-7844-9786 \\ koblianska@protonmail.com
}

Ведення натурального господарства в сільськогосподарській галузі є перешкодою на шляху ефективного розвитку галузі через неефективне використання ресурсів (передусім, праці та землі), створює загрози продовольчій безпеці через недостатнє гарантування якості та безпечності продукції у таких господарствах, а такожє перешкодою на шляху сталого розвитку сільських територій через малий внесок натуральних господарств у розвиток локальної спільноти. 3 використанням методів порівняння та кореляційного аналізу у статті ідентифріковано структурні зрушення, що мали місце за десятирічний період (2008-2018рр.) у приватному секторі з виробництва продовольства в Україні, а також визначено зв'язки між соціально-економічними параметрами розвитку сільських територій та особливостями ведення підсобного господарювання, зокрема, тенденціями комерціалізації/натуралізації діяльності господарств населення. Використовуючи кореляційний аналіз також визначено зв'язки між соціально-економічними умовами розвитку регіонів та особливостями ведення (комериіалізації/натуралізації) особистих селянських господарсть, що фрактично постають як форма підприємницької діяльності в приватному секторі сільськогосподарського виробництва. Отримані результати свідчать про необхідність вироблення системної політики, спрямованої на підтримку малого та середнього підприємництва в сільськогосподарскій галузі.

Ключові слова: натуральне господарювання, господарства населення, комерціалізація діяльності агровиробників, структурні зрушення в сільському господарстві, особисті селянські господарства, підприємниитво.

DOI: https://doi.org/10.32845/bsnau.2019.2.4

Вступ. Розвиток підприємницького середовища в сільській місцевості є однією з передумов соціально-економічного відродження сільських територій, забезпечення розвитку локальних спільнот відповідно до принципів сталості. Потужний потенціал розвитку підприємництва закладений у масивному прошарку дрібних агровиробників - господарств населення, що виробляють майже половину валового обсягу продукції сільського господарства. Виробляючи значну частку продукції кінцевого споживання, такі господарські форми постають як основа забезпечення продовольчої безпеки. Практикуючи традиційні для місцевості способи (та культури) ведення сільськогосподарської діяльності, вони виступають запорукою збереження природно-ресурсного потенціалу місцевості, зберігачами історичних традицій та культури господарювання. У цьому полягають важливі соціо-еколого-економічні функції таких господарств. 3 іншого боку, така господарська діяльність має, переважно, натуральний характер (адже більша частина продукції використовується для забезпечення власних потреб у продовольстві, і це прямо передбачено чинним законодавством, зокрема, законом (Про особисте, 2003). В умовах ринкових та інституційних транссрормацій в аграрній сфері, що з відкриттям ринку землі набудуть нового змісту та більш інтенсивного характеру, постає питання про подальше майбутнє «господарств населення»: зникнення, збереження існуючої форми чи комерціалізація успішних господарств з утворенням повноцінних підприємницьких одиниць? Очевидно, що найбільш логічним є останній шлях розвитку, адже саме це, власне, і було головною метою аграрної реформи, розпочатої ще наприкінці минулого століття. 3 цих позицій, актуальним та своєчасним є вивчення тенденцій розвитку господарств населення за умов ринкових трансформацій, ідентифікація чинників, що мають вплив на процеси комерціалізації (чи навпаки, натуралізації) їхньої діяльності.

Аналіз останніх досліджень і публікацій. Ризики

поширення натуральної форми господарювання з точки зору продовольчої безпеки, суспільної ефективності виробництва та розвитку сільських територій детально досліджені у працях вчених та науковців ЄС (Buchenrieder, 2009; Fritzsch, 2010; Alexandri, 2015; Davidova, 2014; Forgács, 2012; JędrzejczakGas, 2018) i, зокрема, охоплюють такі: низька ефективність використання ресурсів, низька технологічність та безпечність продукції, малий внесок у розвиток локальних спільнот, неформальна зайнятість та ін. Необхідність подолання проблеми існування та поширення натурального господарювання, зокрема, через запровадження заходів із комерціалізації діяльності таких господарств, $€$ одним із завдань політики сільського розвитку ЄС (Council Regulation, 2005). Водночас, пропонуються й інші потенційні напрями трансформації натуральних господарств: через їхню інтеграцію у ринково-орієнтовані господарства більшого масштабу або ж збереження існуючого статусу-кво (головним чином через соціальну, культурну та екологічну функцію господарств) (Davidova, 2011). Деякі інструменти в рамках окреслених напрямів були запроваджені у ЄС (European Parliament, 2013) i очевидним, за результатами імплементації цих заходів $€$ те, що у даному питанні немає універсального вірного рішення. В основі формування дієвої політики, спрямованої на подолання проблеми поширення натурального господарювання, повинно бути вивчення причин та мотивів, які визначають залучення населення до ведення такої форми господарювання, а відповідно, й її комерціалізації.

Причини утворення та поширення такого явища як натуральне господарювання досі остаточно не з'ясовані (Buchenrieder, 2009). В окремих дослідженнях (Fredriksson et al., 2016) вказується, що потреба у веденні натурального господарства зростає у міру збільшення економічного навантаження на одного працюючого члена господарства, тоді як альтернативний (позафермовий) дохід скорочує потребу у

Вісник Сумського національного аграрного університету Серія «Економіка і менеджмент», випуск 2 (80), 2019 
натуральному споживанні та дозволяє збільшити обсяг продукції, що продається на ринку (Fredriksson et al., 2016; Csata, 2018), а отже - є чинником комерціалізації діяльності господарства. Давідова С. відзначає, що така форма господарювання є наслідком ринкової недосконалості, але, разом із тим, можуть бути виділені ринково-орієнтовані натуральні ферми та натурально-орієнтовані ферми ('market-oriented subsistence farmers' and 'subsistence-oriented farmers'). Перші мають сильну мотивацію виробляти на ринок, а залишки споживають, вони більше реагують на ринкові та політичні сигнали (Davidova, 2011, p. 505).

Однією з причин збереження натуральних господарств $€$ ментальність, зокрема, пануюча недовіра населення до формальних інституцій та необхідність створення «запасу міцності», що має убезпечити людину від бідності в умовах неналежної державної системи гарантування добробуту (World Bank, 2016, р. 27). Узагальнюючи результати досліджень вчених щодо даної проблеми в Угорщині, Молдові, Румунії (Giurca, 2008; Alexandri, 2015; Forgács, 2012; Fritzsch, 2010) слід підкреслити, що загальною проблемою є морально-етична основа ведення натурального господарства у напівлегальній формі, яка полягає у намаганні уникнути оподаткування і використанні для цього наявних можливостей, уникненні відповідальності за розвиток громади, патерналістських настроях, що також характерно й для України (Строченко та Коблянська, 2016). Серед причин розповсюдження натурального господарювання саме у східноєвропейському просторі можна виділити історико-культурні, зумовлені пануванням соціалістичного устрою. Зокрема, недосконалість відносин (неповнота трансформаційних звершень) щодо розпорядження земельними ділянками, які були передані у приватну власність, породжує проблему натуралізації сільськогосподарської діяльності в приватному секторі. Так, Лерман 3. відзначає, що здійснення розпаювання та приватизації земельних ділянок повинно йти рука об руку із забезпеченням вільного руху прав на ці земельні ділянки (продаж, оренда), підкреслюючи, що це є необхідною умовою ефективних реформ земельних відносин у постсоціалістичних країнах (Lerman, 2002). Разом із тим, не всі країни здійснили ці перетворення своєчасно (Lerman, 2012), зокрема, й Україна.

Зрештою, перераховані вище - це чинники зовнішнього характеру, сформовані загальними історико-культурними, організаційно-політичними та соціально-економічними умовами. Водночас, існує й ряд внутрішніх чинників, які визначають схильність людини (землевласника) до тієї чи іншої форми використання належної йому земельної ділянки. Ці чинники включають, серед іншого, такі: вік, рівень освіти, психологічні особливості та ін. Залежно від цих факторів у роботі (Buchenrieder et al., 2009) виділено такі типи власників натуральних господарств як сільські пенсіонери, фермери, сільські диверсифікатори, сільські початківці; змодельовано різні політичні стратегії, спрямовані на підвищення ефективності господарювання, релевантні для кожного з типів власників. Поєднуючи в єдиному контексті зовнішні фактори та внутрішні особливості власників домогосподарств, Давідова С. виокремлює такі типи фермерів: фермери, вимушені вести натуральне господарювання через ринкову недосконалість та нерозвинену мережу соціального захисту, для яких напівнатуральне господарювання $€$ стратегією вирішення цих проблем; фермери з частковою зайнятістю, що отримують доходи й з інших джерел; напівнатуральні фермери за власним вибором, для яких така діяльність також і хобі, певний стиль життя (Davidova, 2011, p. 505). Незважаючи на певні відмінності наведених підходів, вчені $€$ спільними у тому, що натуральні господарства - це гетерогенна група власників ферм з різною мотивацією та ступенем схильності до сільського господарства, що визначає складність знаходження однозначних ефективних та дієвих заходів політичного регулювання (Buchenrieder, 2009; Davidova, 2014).

3 огляду на масштаби поширення натурального господарювання в Україні та ризики подальшого ігнорування цієї проблеми в площині політичних рішень щодо сільського господарства та розвитку сільських територій, а також відсутність досліджень у вітчизняному науковому просторі (окремі аспекти даної проблеми досліджено у (Строченко та Коблянська, 2016; Strochenko et al., 2017), соціально-економічні та правові проблеми функціонування ОСГ досліджено у працях (Свиноус, 2009; Мішенін та ін., 2011; Маренич, 2016), виникає об'єктивна необхідність вивчення фракторів, що мають вплив на збереження та поширення практик натурального господарювання, а також ідентифікації чинників, що справляють позитивний вплив на комерціалізацію діяльності господарств населення, як основного виробника агропродукції кінцевого споживання в країні. Це визначає мету даного дослідження та, на наш погляд, повинно закласти основу для формування дієвої політики, спрямованої на структурні зрушення в сільськогосподарському виробництві та сільській економіці відповідно до умов сьогодення: євроінтеграції, експансії України на світовому агропродовольчому ринку, ринкових перетворень та ін.

Методи дослідження. Для проведення дослідження використано офріційні статистичні дані Державної служби статистики України. На основі порівняння змін основних параметрів, що характеризують сільськогосподарську діяльність господарств у часі, досліджуються структурні зрушення у приватногосподарському секторі сільськогосподарської галузі країни. 3 використанням методу кореляції проаналізовано як зв'язок соціально-економічних параметрів розвитку сільської місцевості із особливостями ведення підсобного господарювання за десятирічний період 2008-2018, так і вивчено зв'язок характерних рис практик особистого селянського господарювання та особливостей регіонального контексту.

Виклад основного матеріалу. Передусім, слід прокоментувати поширеність такого явища як натуральне господарювання в Україні. Станом на початок 2019 року в Україні налічувалось 8175,8 тис. домогосподарств населення, що тією чи іншою мірою по'вязані з веденням сільськогосподарського виробництва (ідентифіковані як особисті підсобні господарства). Для ілюстрації масштабності (поширеності) цього явища зазначимо, що це більш ніж половина - 55 \% від загальної чисельності домогосподарств в країні (Основні, 2018; Соціально-демограсрічні, 2018). Сукупно господарства населення, до складу яких, за методологією Державної служби статистики України віднесено домогосподарства, що здійснюють сільськогосподарську діяльність як з метою самозабезпечення продуктами харчування, так і з метою виробництва товарної сільськогосподарської продукції (домогосподарства у сільській місцевості, домогосподарства у міський місцевості, а також фізичних осіб - суб'єктів підприємницької діяльності, які провадять свою діяльність у галузі сільського господарства без створення юридичної особи (Про затвердження, 2015). Господарства населення у 2018 р. виробили 
41,24 \% продукції сільського господарства в Україні (для порівняння - фермерські господарства - лише трохи більше $7 \%)$. При цьому, господарства населення $є$, фактично основним виробником такої продовольчої продукції як картопля, культури овочеві та баштанні продовольчі (92\%), культури плодові, ягідні та виноград (79,74\%), продукції тваринництва, зокрема молока $(73,14 \%)$, вовни (87,5\%) та іншої продукції тваринництва, у тому числі меду (98 \% за даними 2017 р.). Господарства населення забезпечують більш ніж третину загального виробництва м'яса $(36,14 \%)$, а також значну частку виробництва яєць $(44,83 \%)$ (Сільське, 2018). Цим визначається їхня вагома роль у забезпеченні населення продовольством та гарантуванні продовольчої безпеки.

Відповідно до типології, запропонованої у (Davidova, 2014), сфрормований в Україні клас малих виробників продовольства - «господарства населення» - фактично провадить натуральну форму ведення господарювання. Підтвердженням тому $є$ те, що за даними 2018 р., для вирощування продукції лише для власних потреб у середньому використовується 20,7 \% земельної площі у міських господарствах, тоді як для власних потреб і на продаж - лише 1,3 \%. У сільській місцевості для вирощування продукції лише для власних потреб відводиться в середньому 15,7 \% земельної площі господарства, тоді як для власних потреб і на продаж - в середньому 10,0 \% (Основні, 2018). Дані про розподіл земельної площі використовуємо через відсутність достовірних оцінок щодо обсягу та частки продукції, яка реалізується господарствами на ринку.

3 огляду на поширеність практик натурального господарювання, дослідимо причини та масштаби функціонування підсобних господарств в Україні. Першочергово прокоментуємо загальні тенденції динаміки показників щодо їхньої діяльності у сільських та міських поселеннях (табл. 1).

Таблиця 1 - Профіль особистих підсобних господарств у сільських та міських поселеннях, 2008/2018 рр. (розраховано за даними Державної служби статистики України http://www.ukrstat.gov.ua/)

\begin{tabular}{|c|c|c|c|c|}
\hline \multirow[t]{2}{*}{ Показник } & \multicolumn{2}{|c|}{$\begin{array}{l}\text { Розміщені у сільських } \\
\text { населених пунктах }\end{array}$} & \multicolumn{2}{|c|}{$\begin{array}{l}\text { Розміщені у міських } \\
\text { населених пунктах }\end{array}$} \\
\hline & $2008 \mathrm{p}$. & $2018 \mathrm{p}$. & $2008 \mathrm{p}$. & $2018 \mathrm{p}$. \\
\hline Кількість домогосподарств, тис. од. & 5334,2 & 4873,6 & 11864,8 & 10061,3 \\
\hline Середній розмір, осіб & 2,74 & 2,67 & 2,54 & 2,54 \\
\hline Частка домогосподарств, де немає працюючих осіб, \% & 50,2 & 44,2 & 28,9 & 31,2 \\
\hline Середня кількість працюючих у розрахунку на одне домогосподарство, осіб & 0,8 & 0,9 & 1,2 & 1,1 \\
\hline Коефіцієнт економічного навантаження на працюючого члена господарства, разів & 3,41 & 3,01 & 2,09 & 2,30 \\
\hline Частка витрат на продовольчі товари, у грошових витратах, \% & 55,4 & 44,60 & 49,6 & 49,80 \\
\hline $\begin{array}{l}\text { Частка оплати праці та доходу від підприємницької діяльності та самозайнятості у } \\
\text { сукупних ресурсах, \% }\end{array}$ & 36,4 & 47,00 & 61,4 & 67,30 \\
\hline Особисті підсобні господарства, що мають земельні ділянки, тис. од. & 5262,6 & 4799,8 & 4454,7 & 3376,0 \\
\hline Частка домогосподарств, що мають земельні ділянки, \% & 98,66 & 98,49 & 37,55 & 33,55 \\
\hline Середній розмір земельної ділянки, соток & 314,3 & 292,1 & 21,1 & 46,9 \\
\hline Частка домогосподарств, що утримують худобу, птицю і бджіл, \% & 80,9 & 76,0 & 9,2 & 8,1 \\
\hline \multicolumn{5}{|c|}{$\begin{array}{l}\text { Розподіл земельної площі за видом її використання домогосподарством (серед домогосподарств, які мають земельні ділянки і } \\
\text { використовують їх за напрямом), \% }\end{array}$} \\
\hline для вирощування продукції лише для власних потреб & 13 & 15,7 & 42,3 & 20,7 \\
\hline для вирощування продукції для власних потреб і на продаж & 16,4 & 10,0 & 3,9 & 1,3 \\
\hline здається в оренду & 69,6 & 73,2 & 52,8 & 77,3 \\
\hline лише для відпочинку & 0 & 0,0 & 0,2 & 0,1 \\
\hline тільки почали освоювати та ін. & 1 & 1,1 & 0,8 & 0,6 \\
\hline
\end{tabular}

Отже, як видно з наведених у табл. 1 даних, має місце скорочення кількості як домогосподарств загалом, так і особистих підсобних господарств у сільській та міській місцевостях. Особливо відмітним при цьому є зниження частки останніх у міських поселеннях (на 4,0\%). При цьому відбувається зменшення середнього розміру земельної ділянки домогосподарства у сільській місцевості (на 22,2 соток), але майже двократне збільшення середнього розміру ділянки міського домогосподарства. Скорочується питома вага домогосподарств, що утримують худобу, птицю і бджіл в сільських та міських поселеннях; сільські домогосподарства стають більш натуралізованими (за часткою земельної площі, що відводиться для вирощування продукції для власних потреб), зменшуючи частку площ під виробництвом продукції і на продаж також. Останнє справедливо й для міських домогосподарстввласників земельних ділянок, які, на додачу, суттєво (у більш ніж 2 рази) скоротили питому вагу земельної площі, відведеної для самозабезпечення продовольством. Відмітною для сільських та міських господарств $€$ тенденція до здавання земельних ділянок в оренду. Це, в свою чергу, є одним із шляхів подолання натуралізації господарської діяльності (European Parliament, 2013).

Разом із тим, міські домогосподарства не $є$ показовими в сенсі трансформації натурального господарювання у ринково-орієнтовані форми. Передусім, через традиції ведення підсобного господарювання в міських населених пунктах $з$ метою, першочергово, задоволення власних потреб у продовольстві та відпочинку, а з іншого боку - через невеликий розмір земельних ділянок. Тож далі дослідимо, які чинники є важливими з точки зору сприяння ринковим трансфрормаціям натуральних господарств населення у сільській місцевості (табл. 2).

Отже, як свідчать результати проведених розрахунків (табл. 2) та наявні статистичні дані (табл.1), загальна тенденція щодо скорочення кількості підсобних домогосподарств у сільській місцевості, що мають земельні ділянки, тісно та позитивно корелює зі зменшенням середнього розміру домогосподарства $(0,9)$, зменшенням частки домогосподарств, де немає працюючих осіб $(0,64)$ та скороченням коефіцієнту еко- 
номічного навантаження на одного працюючого у господарстві $(0,6)$. Також зниження частки витрат на продовольчі товари у грошових витратах домогосподарства посередньо, але позитивно корелює із кількістю підсобних господарств, що мають земельні ділянки $(0,53)$. Збільшення частки активного доходу в сукупних ресурсах домогосподарства також пов'язане зі зменшенням кількості домогосподарств, що мають земельні ділянки. Але найбільший вплив на їхню кількість має зниження загальної кількості сільських домогосподарств $(1,0)$, тобто депопуляція сільської місцевості). Тому дослідимо вплив чинників на поширеність таких підсобних господарств. Зі зростанням середньої кількості працюючих в середньому в господарстві знижується питома вага домогосподарств, що мають земельні ділянки $(-0,44)$.

Таблиця 2 - Результати кореляційного аналізу зв'язку характеристик ведення підсобних господарств у сільських поселеннях із соціально-економічними умовами розвитку сільських поселень, 2008-2018 (розраховано за даними Державної служби статистики України http://www.ukrstat.gov.ua/)

\begin{tabular}{|c|c|c|c|c|c|c|c|c|c|c|c|}
\hline Показник / Показник & 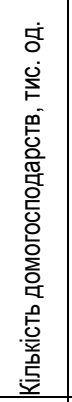 & 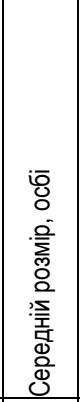 & 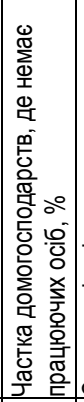 & 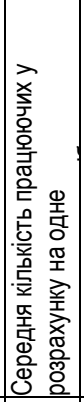 & 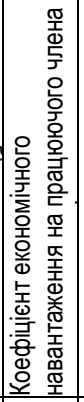 & 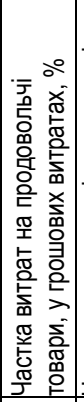 & 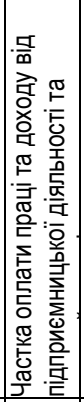 & 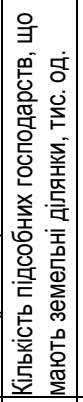 & 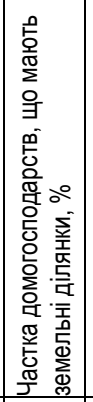 & 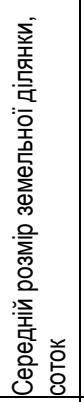 & 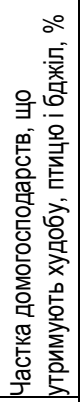 \\
\hline Кількість підсобних господарств, що мають земельні діляң & 1,00 & 0,90 & 0,64 & $-0,35$ & 0,60 & 0,53 & $-0,54$ & 1,00 & 0,47 & 0,19 & 0,62 \\
\hline Частка домогосподарств, що мають земельні ділянки, \% & 0,38 & 0,56 & 0,28 & $-0,44$ & 0,33 & $-0,24$ & $-0,13$ & 0,47 & 1,00 & 0,62 & 0,67 \\
\hline Середній розмір земельної ділянки, соток & 0,13 & 0,26 & 0,39 & $-0,48$ & 0,51 & $-0,41$ & $-0,01$ & 0,19 & 0,62 & 1,00 & 0,55 \\
\hline Частка домогосподарств, що утримують худобу, птицю і бджіл, \% & 0,58 & 0,67 & 0,71 & $-0,66$ & 0,63 & 0,17 & $-0,54$ & 0,62 & 0,67 & 0,55 & 1,00 \\
\hline \multicolumn{12}{|l|}{ Розподіл земельної площі за видом її використання домогосподарством, \%: } \\
\hline для вирощування продукції лише для власних потреб & $-0,87$ & $-0,77$ & $\mid-0,59$ & 0,41 & \begin{tabular}{|l|}
$-0,67$ \\
\end{tabular} & \begin{tabular}{|l|}
$-0,37$ \\
\end{tabular} & 0,45 & $-0,88$ & $-0,49$ & $-0,52$ & $-0,61$ \\
\hline для вирощування продукції для власних потреб і на продаж & 0,68 & 0,66 & 0,64 & $-0,56$ & 0,74 & 0,45 & $-0,69$ & 0,69 & 0,41 & 0,55 & 0,65 \\
\hline дається в оренду & $-0,29$ & $-0,31$ & \begin{tabular}{|c|}
$-0,59$ \\
\end{tabular} & 0,63 & \begin{tabular}{|l|}
$-0,70$ \\
\end{tabular} & $-0,36$ & 0,70 & \begin{tabular}{|c|} 
\\
\end{tabular} & $-0,17$ & $-0,49$ & 0,5 \\
\hline & & & & 841 & 251 & & 0,00 & & -0 , & 0,30 & \\
\hline
\end{tabular}

Середній розмір земельної ділянки позитивно, хоча посередньо пов'язаний із питомою вагою домогосподарств, що мають земельні ділянки $(0,62)$, і є тим нижчим, чим більшою $є$ кількість працюючих у середньому в господарстві (0,48), а також більшою частка витрат на продовольчі товари у грошових витратах господарства $(-0,41)$. Також середній розмір земельної ділянки позитивно та посередньо пов'язаний із коефіцієнтом економічного навантаження: чим він менший, тим меншим є розмір земельної ділянки $(0,51)$.

Поширеність такого явища як утримання у підсобному господарстві худоби, тісно та позитивно корелює з середнім розміром господарства $(0,67)$ та часткою домогосподарств, де немає працюючих осіб $(0,71)$, тоді як зі збільшенням середньої кількості працюючих - схильність до ведення тваринницької діяльності зменшується $(-0,66)$. Це ж справедливо й для збільшення частки активного доходу у сукупних ресурсах домогосподарства $(-0,54)$. Зі зменшенням економічного навантаження поширеність тваринницької діяльності також зменшується $(0,63)$.

Важливою характеристикою домогосподарства, що має земельну ділянку, є спосіб її використання. Тож, зі зменшенням середнього розміру домогосподарства збільшується частка площі, що використовується для забезпечення власних потреб у продовольстві $(-0,77)$. Це є справедливим і щодо кількості домогосподарств, в яких немає працюючих $(-0,59)$ і коефіцієнту економічного навантаження $(-0,67)$. Зі зменшенням частки витрат на продовольчі товари у грошових витратах (що можна трактувати як зростання грошових доходів) господарства, домогосподарства використовують земельну площу більшою мірою для забезпечення власних потреб у продовольстві $(-0,37)$ та здають в оренду $(-0,36)$. Також тісним та позитивним $є$ зв'язок між коефріцієнтом економічного навантаження та спрямуванням площі для вирощування продукції у тому числі й на продаж $(0,74)$. Середня кількість працюючих позитивно, але посередньо корелює із використанням земельної площі для здавання в оренду $(0,63)$, забезпечення власних потреб у продовольстві $(0,41)$, але обернено - із використанням її для вирощування продукції, у тому числі й на продаж $(-0,56)$. Отже, підкреслимо, що комерціалізація діяльності підсобних господарств тісно пов'язана:

- із часткою господарств, де немає працюючих - чим меншою $€$ ця частка, тим менш ринково активними $€$ господарства $(0,64)$;

- із коефіцієнтом економічного навантаження - чим він $€$ більшим, тим більш активною $є$ ринкова діяльність господарства $(0,74)$;

- із рівнем витрат на продовольство у грошових витратах - чим вищим він $€$ тим більш ринково орієнтованим $€$ господарство $(0,45)$;

- із середньою кількістю працюючих в господарстві чим вища їх кількість, тим менш ринково активним $€$ господарство $(-0,56)$;

- із часткою активного доходу у сукупних ресурсах (чим вищою вона $€$, тим менш ринково активним $€$ господарСтво $-0,69)$.

Отже, сільські підсобні господарства, що використовують земельну ділянку більшою мірою для вирощування продукції для власних потреб і на продаж - це господарства непрацюючих осіб. У випадку пожвавлення соціально-економі- 
чної ситуації (більші можливості для зайнятості) домогосподарства спрямовують земельні ділянки для забезпечення власних потреб у продовольстві та здають їх в оренду.

Зрештою, дослідимо яким чином соціально-економічні чинники розвитку регіонів позначаються на діяльності та розвиткові особистих селянських господарств - певної легальної форми ведення сільськогосподарської діяльності домогосподарством, що також включає й продаж продуктів продовольства (Табл. 3).

Коментуючи результати розрахунків (Табл. 3), слід підкреслити, що кількість ОСГ тісно пов'язана із кількістю сільських домогосподарств у регіонах $(0,89)$. Разом із тим, це не $є$ справедливим щодо площ ОСГ: зі збільшенням частки сільських домогосподарств загальна площа ОСГ зменшується $(-0,28)$, тобто зі зростанням їх кількості та питомої ваги, розміри зменшуються. Кількість ОСГ буде вищою у тих регіонах, де середній розмір господарства є більшим $(0,5)$ (що характерно для сільської місцевості). ОСГ - це, переважно, господарства, що утримують худобу і птицю $(0,84)$. Скоріше, вони створюються у тих регіонах, де вищою є середня кількість працюючих у одному господарстві $(0,55)$. Цікавим $€$ те, що зі зростанням рівня безробіття кількість ОСГ буде скорочуватись, тобто ця діяльність не сприймається як належна альтернатива заробітку $(-0,54)$, а скоріше як часткова зайнятість. У регіонах, де кількість господарств, в яких немає жодного працюючого, є вищою, загальна площа, зайнята ОСГ, буде вищою $(0,37)$, це справедливо і щодо кількості міських домогосподарств $(0,43)$. При цьому площі ОСГ більшою мірою спрямовуються для товарного виробництва зі збільшенням рівня урбанізації, а також кількістю домогосподарств, де немає жодного працюючого $(0,46)$. У цьому випадку ці площі формуються за рахунок орендованих земель $(0,66$ та 0,56, відповідно). Кількість ОСГ, як зазначено вище, корелює із кількістю господарств, що утримують худобу, птицю і бджіл $(0,84)$. Причому за зростання кількості таких господарств, площі ОСГ спрямовуються на обслуговування житлового будинку $(0,79)$ та ведення особистого селянського господарства $(0,53)$, але виводяться із товарного виробництва $(-0,33)$ та орендних відносин $(-0,46)$.

Таблиця 3 - Результати кореляційного аналізу зв'язку параметрів, що характеризують ведення особистих селянських господарств із соціально-економічними умовами розвитку регіонів, 2008-2018

(розраховано за даними Державної служби статистики України http://www.ukrstat.gov.ua/)

\begin{tabular}{|c|c|c|c|c|c|c|}
\hline $\begin{array}{l}\text { Показник/ } \\
\text { Показник }\end{array}$ & 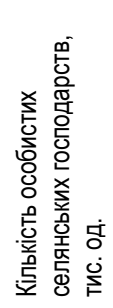 & 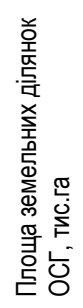 & 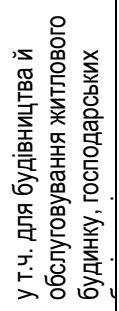 & 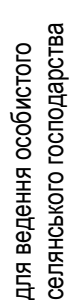 & 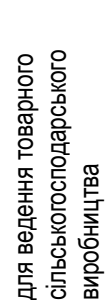 & 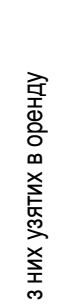 \\
\hline Кількість домогосподарств, що розміщені у міських населених пунктах, тис. од. & $-0,14$ & 0,43 & $-0,11$ & $-0,18$ & 0,57 & 0,66 \\
\hline $\begin{array}{l}\text { Кількість домогосподарств, що розміщені у сільських населених пунктах, } \\
\text { тис.од. }\end{array}$ & 0,89 & 0,27 & 0,86 & 0,46 & $-0,11$ & $-0,24$ \\
\hline $\begin{array}{l}\text { Питома вага домогосподарств, що розташовані у сільських населених пунктах, } \\
\text { \% }\end{array}$ & 0,59 & $-0,28$ & 0,54 & 0,39 & $-0,61$ & $-0,74$ \\
\hline Середній розмір домогосподарства, осіб & 0,50 & 0,04 & 0,44 & 0,42 & $-0,27$ & $-0,46$ \\
\hline Кількість домогосподарств, що мають земельні ділянки, тис. од. & 0,29 & 0,29 & 0,32 & 0,00 & 0,26 & 0,31 \\
\hline Кількість домогосподарств, які утримують худобу, птицю і бджіл, тис. од. & 0,84 & 0,08 & 0,79 & 0,53 & $-0,33$ & $-0,46$ \\
\hline Кількість домогосподарств, де немає жодного працюючого, тис. од. & $-0,09$ & 0,37 & $-0,01$ & $-0,11$ & 0,46 & 0,56 \\
\hline Середня кількість працюючих у розрахунку на одне господарство, осіб & 0,55 & 0,03 & 0,39 & 0,08 & $-0,11$ & $-0,18$ \\
\hline Коефіцієнт економічного навантаження на одного працюючого, разів & $-0,20$ & $-0,01$ & $-0,04$ & 0,38 & $-0,19$ & $-0,29$ \\
\hline Рівень економічної активності у віці 15-70 років, \% & $-0,28$ & $-0,16$ & $-0,29$ & $-0,62$ & 0,21 & 0,28 \\
\hline $\begin{array}{l}\text { Рівень безробіття населення у відсотках до економічно активного на } \\
\text { 15-70 років, \% }\end{array}$ & $-0,54$ & $-0,32$ & $-0,48$ & $-0,22$ & $-0,12$ & $-0,03$ \\
\hline $\begin{array}{l}\text { Частка неформально зайнятого населення відносно кількості зайнятого } \\
\text { населення, \% }\end{array}$ & 0,01 & $-0,14$ & 0,05 & 0,03 & $-0,18$ & 0,34 \\
\hline
\end{tabular}

Висновки. Отже, результати проведеного дослідження свідчать про те, що наразі в Україні має місце зниження кількості домогосподарств, що задіяні в сільськогосподарському виробництві як для самозабезпечення продовольством, так і з метою виробництва продукції для продажу. Причому має місце не лише абсолютне скорочення кількості таких господарств, але зниження їх питомої ваги у загальній кількості домогосподарств, тобто знижується поширеність цього явища. Фактично, мають місце «природні» структурні зрушення в цьому секторі, про можливість яких наголошено у роботі (Buchenrieder et al. 2009). Разом із тим, слід звернути увагу на характер цих структурних зрушень: з огляду на вияв- лені чинники комерціалізації (натуралізації) діяльності підсобних господарств в сільській місцевості, має місце поступове зникнення індивідуалізованого сільськогосподарського виробництва із відведенням сільськогосподарських земель у користування крупним агровиробникам. У цьому криється загроза ефективному розвитку сільських територій та сільськогосподарської галузі, адже саме індивідуальні форми господарювання розглядаються як основа для розвитку ефективного сільського господарства в ринковій економіці (Lerman, 2002), а становлення такої моделі господарювання в Україні, власне, було головною метою здійснюваної вже майже 20 років земельно-аграрної реформи. Тож, не зменшуючи важли- 
вості розв'язання проблеми ведення напівлегального натурального господарювання, слід звернути увагу на інший аспект даної проблеми - відсутність стратегії підтримки становлення моделі індивідуального фермерства, що має протидіяти ризикам індустріалізованого агровиробництва. Адже, як свідчать результати проведеного аналізу, у випадку пожвавлення економічної активності в сільській території (периферійних територіях), матиме місце зникнення класу приватних малих агровиробників. У цьому криються ризики забезпечення продовольчої безпеки, адже саме ці структури виробляють основну частину продукції споживчого кошика.

Слід також наголосити на тому, що для розробки політичних заходів, які мали би сприяти розвитку приватних фее- рмерських господарств з наявного числа ринково-орієнтованих господарств населення, необхідними є більш глибокі спеціальні дослідження, спрямовані на визначення мотивів та чинників, що визначають схильність особи конкретного віку, в конкретній місцевості, сформованого стилю життя, до продовження натурального господарювання чи комерціалізації виробничої діяльності господарства. Це може становити предмет подальших досліджень у цій сфері.

Подяки. Публікація підготовлена в рамках виконання науково-дослідної роботи молодих вчених «Формування механізму реалізації інтегрованого територіального управління в умовах переходу до сталого розвитку» (№ 0117U006534) за рахунок бюджетних коштів Міністерства освіти і науки України.

\section{Список літератури:}

1. Маренич Т. Г. Трансфрормація особистих селянських господарств у підприємницькі структури. Вісник Харківського національного технічного університету сільського господарства імені Петра Василенка. 2016. Вип. 174. C. 24-34. URL: http://nbuv.gov.ua/UJRN/Vkhdtusg_2016_174_5

2. Мішенін Є. В., Косодій Р.П., Бутенко В.М. Соціально-економічні та фінансові проблеми сталого сільського розвитку: монографрія. Суми: ТОВ «ТД Папірус», 2011. 334 с.

3. Основні сільськогосподарські характеристики домогосподарств у сільській місцевості: статистичний збірник (за 2008-2018 pp.). URL: http://www.ukrstat.gov.ua/

4. Про затвердження Методологічних положень з організації державних статистичних спостережень зі статистики рослинництва: Наказ Державної служби статистики України від 28.12.2015 № 370. (за станом на 12.07.2019). URL: https://zakon.rada.gov.ua/rada/show/v0370832-15/print

5. Про особисте селянське господарство : Закон України від 15.05.2003 № 742-IV (за станом на 20.07.2019). URL: http://zakon.rada.gov.ua/go/742-15.

6. Свиноус, І. В. Теоретико-методологічні проблеми ототожнювання понять «особисте селянське господарство» та «суб'єкт підприємницької діяльності». Актуальні проблеми розвитку економіки регіону. 2009. Вип. 5, т. 2. С. $158-163$.

7. Сільське господарство України: статистичний збірник (за 2009-2018рp.). URL: http://www.ukrstat.gov.ua/

8. Соціально-демографічні характеристики домогосподарств України (за 2009-2018 pp.). URL: http://www.ukrstat.gov.ual

9. Строченко Н.І., Коблянська І.І. Сутнісно-організаційні трансформації господарювання на селі як основа сталого сільського розвитку в Україні. Маркетинг і менеджмент інновацій. 2016. № 3. С. 293-308.

10. Buchenrieder, Gertrud \& Fritzsch, Jana \& Wegener, Stefan \& Curtiss, Jarmila \& Gomez y Paloma, Sergio, 2009. "Semisubsistence farm households and the non-farm rural economy - Perspectives and challenges," 111th Seminar, June 26-27, 2009, Canterbury, UK 52804, European Association of Agricultural Economists. https://www.researchgate.net/publication/46472310

11. Davidova, S. (2011). Semi-Subsistence Farming: An Elusive Concept Posing Thorny Policy Questions. Journal of Agricultural Economics, 62(3), 503-524. https://doi.org/10.1111/j.1477-9552.2011.00313.x

12. Davidova, S. (2014). Small and Semi-subsistence Farms in the EU: Significance and Development Paths. EuroChoices, 13(1), 5-9. https://doi.org/10.1111/1746-692X.12043

13. EUROPEAN PARLIAMENT (2013) Semi-subsistence farming: value and directions of development. Davidova S., Bailey A., Dwyer J., Gorton M., Thomson K. URL: https://www.europarl.europa.eu/RegData/etudes/etudes/join/2013/495861/ -IPOLAGRI_ET(2013)495861_EN.pdf (доступно 19.01. 2019).

14. Fredriksson L., Bailey A., Davidova S., Gorton M. and Traikova D. (2016). Pathways to Commercialisation of SemiSubsistence Farms: Lessons Learnt from Rural Transformation in Central and Eastern European Countries. The Food and Agriculture Organization (FAO) of the United Nations. URL: http://www.fao.org/3/a-bp145e.pdf . (доступно 15.01.2019).

15. Jędrzejczak-Gas, J. (2018). Self-employment as a Form of Entrepreneurship Development in Rural Areas in Poland. In International Scientific Days 2018. Towards Productive, Sustainable and Resilient Global Agriculture and Food Systems: Proceedings. Wolters Kluwer ČR, Prague. https://doi.org/10.15414/isd2018.s5.03

16. Strochenko, N., Koblianska I., \& Markova, O. Structural Transformations in Agriculture as Necessary Condition for Sustainable Rural Development in Ukraine. Journal of Advanced Research in Law and Economics. 2017. Volume VIII, Spring, 1(23). P. 237 - 249. DOI: 10.14505/jarle.v8.1(23).27.

17. Alexandri, C., Luca, L., \& Kevorchian, C. (2015). Subsistence Economy and Food Security - The Case of Rural Households from Romania. Procedia Economics and Finance, 22, 672-680. https://doi.org/10.1016/S2212-5671(15)00282-8

18. Forgács, C. (2012). Semi-subsistence farming situation and policy - the example of Hungary. Applied Studies In Agribusiness And Commerce, 6(1-2), 143-148. https://doi.org/10.19041/Apstract/2012/1-2/20

19. Fritzsch J., Wegener S., Buchenrieder G., Curtiss J., Gomez Y Paloma S., Burrell A. (2010). Economic Prospects for Semisubsistence Farm Households in EU New Member States. The European Commission's science and knowledge service. URL: 
http://publications.jrc.ec.europa.eu/repository/bitstream/JRC58621/jrc58621.pdf - (доступно 12.01.2019).

20. Lerman, Zvi. (2012). Land reform and farm performance in Europe and Central Asia: a 20 year perspective. Discussion Papers 120260, Hebrew University of Jerusalem, Department of Agricultural Economics and Management.

21. Lerman, Zvi. (2002). Land Policies and Evolving Farm Structures in Transition Countries. DOI:10.1596/1813-9450-2794

22. Csata, A. (2018). Analysis of Accessing Rural Development Funds. Acta Universitatis Sapientiae, Economics and Business, 6(1), 113-134. https://doi.org/10.1515/eb-2018-0006

23. Giurca, D. (2008) Semi-Subsistence Farming - Prospects for the Small Romanian Farmer to Choose between a "Way of Living" or Efficiency," Agricultural Economics and Rural Development, Institute of Agricultural Economics. vol. 5(3-4). P. 215-230. URL: ftp://www.ipe.ro/RePEcliag/iag_pdf/AERD0804_215-230.pdf (доступно 12.01.2019).

24. Council Regulation (EC) No 1698/2005 of 20 September 2005 on support for rural development by the European Agricultural Fund for Rural Development (EAFRD) URL: http://data.europa.eu/eli/reg/2005/1698/2011-12-21 (доступно 12.01.2019).

\section{References:}

1. Marenych, T.G. (2016). Transformatsiia osobystykh selianskykh hospodarstv u pidpryiemnytski struktury [Transformation of private farms in business structure]. Visnyk Kharkivskoho natsionalnoho tekhnichnoho universytetu silskoho hospodarstva imeni Petra Vasylenka [Bulletin of the Kharkiv National Technical University of Agriculture named after Peter Vasylenko]. Vol. 174. P. 2434. URL: http://nbuv.gov.ua/UJRN/Vkhdtusg_2016_174_5

2. Mishenin, Ye. V., Kosodii, R.P., Butenko V.M. (2011). Sotsialno-ekonomichni ta finansovi problemy staloho silskoho rozvytku [Socio-economic and financial problems of sustainable rural development]. Sumy, TOV «TD Papirus». [in Ukrainian].

3. Osnovni silskohospodarski kharakterystyky domohospodarstv u silskii mistsevosti. (2008-2018). [The main agricultural characteristics of rural households]. The State Statistics Service of Ukraine. Retrieved from: http://www.ukrstat.gov.ual

4. Pro zatverdzhennia Metodolohichnykh polozhen z orhanizatsii derzhavnykh statystychnykh sposterezhen zi statystyky roslynnytstva [decree of The State Statistics Service of Ukraine On Approval of Methodological Provisions on the Organization of State Statistical Surveys on Crop Statistics] \# 370 from 28.12.2015. Retrieved from: https://zakon.rada.gov.ua/rada/show/v0370832-15/print

5. Pro osobyste selianske hospodarstvo: Zakon Ukrainy vid 15.05.2003 r. \# 742-IV [Law of Ukraine On Personal Peasant Farm from 15th of May 2003 year \# 742-IV]. Retrieved from: http://zakon.rada.gov.ua/go/742-15. [in Ukrainian].

6. Svynous, I. V. (2009). Teoretyko-metodolohichni problemy ototozhniuvannia poniat «osobyste selianske hospodarstvo» ta "sub"iekt pidpryiemnytskoi diialnosti» [Theoretical and methodological problems equate the concepts of "personal peasant economy" and "business entity"] Aktualni problemy rozvytku ekonomiky rehionu [Actual problems of region's economy]. Vol. 5. Is. 2. P. 158-163. [in Ukrainian].

7. Silske hospodarstvo Ukrainy: statystychnyi zbirnyk (za 2009-2018 rr.) [Agriculture of Ukraine: statistical collection (for 20092018) The State Statistics Service of Ukraine]. Retrieved from: http://www.ukrstat.gov.ua

8. Sotsialno-demohrafichni kharakterystyky domohospodarstv Ukrainy» Statystychnyi zbirnyk (2009-2018 rr.) [Social and Demographic Characteristics of Households of Ukraine: statistical collection (2009-2018)]. The State Statistics Service of Ukraine. Retrieved from: http://www.ukrstat.gov.ual

9. Strochenko, N.I., Koblianska, I.I. (2016). Sutnisno-orhanizatsiini transformatsii hospodariuvannia na seli yak osnova staloho silskoho rozvytku v Ukraini. [Essential and Organizational Transformations of Economy Management in the Countryside as the Basis of Sustainable Rural Development in Ukraine]. Marketynh i menedzhment innovatsii. [Marketing and management of innovations]. Vol.3. P. 293-308.

10. Buchenrieder, Gertrud \& Fritzsch, Jana \& Wegener, Stefan \& Curtiss, Jarmila \& Gomez y Paloma, Sergio. (2009). Semisubsistence farm households and the non-farm rural economy - Perspectives and challenges. 111th Seminar, June 26-27, 2009, Canterbury, UK 52804, European Association of Agricultural Economists. https://www.researchgate.net/publication/46472310

11. Davidova, S. (2011). Semi-Subsistence Farming: An Elusive Concept Posing Thorny Policy Questions. Journal of Agricultural Economics, 62(3), 503-524. https://doi.org/10.1111/j.1477-9552.2011.00313.x

12. Davidova, S. (2014). Small and Semi-subsistence Farms in the EU: Significance and Development Paths. EuroChoices, 13(1), 5-9. https://doi.org/10.1111/1746-692X.12043

13. European Parliament. (2013). Semi-subsistence farming: value and directions of development. Davidova S., Bailey A., Dwyer J., Gorton M., Thomson K. URL: https://www.europarl.europa.eu/RegData/etudes/etudes/join/2013/495861/ -IPOLAGRI_ET(2013)495861_EN.pdf (accessed 19.01.2019).

14. Fredriksson L., Bailey A., Davidova S., Gorton M., Traikova D. (2016). Pathways to Commercialisation of Semi-Subsistence Farms: Lessons Learnt from Rural Transformation in Central and Eastern European Countries. The Food and Agriculture Organization (FAO) of the United Nations. URL: http://www.fao.org/3/a-bp145e.pdf . (accessed 15.01.2019).

15. Jędrzejczak-Gas, J. (2018). Self-employment as a Form of Entrepreneurship Development in Rural Areas in Poland. In International Scientific Days 2018. Towards Productive, Sustainable and Resilient Global Agriculture and Food Systems: Proceedings. Wolters Kluwer ČR, Prague. https://doi.org/10.15414/isd2018.s5.03

16. Strochenko, N., Koblianska I., \& Markova, O. Structural Transformations in Agriculture as Necessary Condition for Sustainable Rural Development in Ukraine. Journal of Advanced Research in Law and Economics. 2017. Volume VIII, Spring, 1(23). P. 237 - 249. DOI: 10.14505/jarle.v8.1(23).27.

17. Alexandri, C., Luca, L., \& Kevorchian, C. (2015). Subsistence Economy and Food Security - The Case of Rural Households from Romania. Procedia Economics and Finance, 22, 672-680. https://doi.org/10.1016/S2212-5671(15)00282-8 
18. Forgács, C. (2012). Semi-subsistence farming situation and policy - the example of Hungary. Applied Studies In Agribusiness And Commerce, 6(1-2), 143-148. https://doi.org/10.19041/Apstract/2012/1-2/20

19. Fritzsch J., Wegener S., Buchenrieder G., Curtiss J., Gomez Y Paloma S., Burrell A. (2010). Economic Prospects for Semisubsistence Farm Households in EU New Member States. The European Commission's science and knowledge service. URL: http://publications.jrc.ec.europa.eu/repository/bitstream/JRC58621/jrc58621.pdf (accessed 12.01.2019).

20. Lerman, Zvi. (2012). Land reform and farm performance in Europe and Central Asia: a 20 year perspective. Discussion Papers 120260, Hebrew University of Jerusalem, Department of Agricultural Economics and Management.

21. Lerman, Zvi. (2002). Land Policies and Evolving Farm Structures in Transition Countries. DOI:10.1596/1813-9450-2794

22. Csata, A. (2018). Analysis of Accessing Rural Development Funds. Acta Universitatis Sapientiae, Economics and Business, 6(1), 113-134. https://doi.org/10.1515/eb-2018-0006

23. Giurca, D. (2008) Semi-Subsistence Farming - Prospects for the Small Romanian Farmer to Choose between a "Way of Living" or Efficiency," Agricultural Economics and Rural Development, Institute of Agricultural Economics. vol. 5(3-4). P. 215-230. URL: ftp://www.ipe.ro/RePEc/iag/iag_pdf/AERD0804_215-230.pdf (accessed 12.01.2019).

24. Council Regulation (EC) No 1698/2005 of 20 September 2005 on support for rural development by the European Agricultural Fund for Rural Development (EAFRD) URL: http://data.europa.eu/eli/reg/2005/1698/2011-12-21 (accessed 12.01.2019).

Koblianska I. I., PhD, Associate Professor, Sumy National Agrarian University (Sumy, Ukraine)

Identification of factors for the subsistence farms commercialization in Ukraine

More than half (55\%) of the total number of households in Ukraine are in one way or another related to agricultural production (identified legally as households plots). Aggregate households in 2018 produced 41.24\% of gross agricultural production (for comparison - farmers - just over 7\%). This determines their crucial role in providing the population with food and guaranteeing country's food security. However, for the most part, household plots are production units classified as subsistence farms.

The risks of the spread of subsistence farming in terms of food security, social efficiency of rural production and development have been extensively explored in the works of EU researchers and hold true as well for the Ukrainian context: low resource use efficiency, low technology and product safety, low contribution to community development, informal employment, etc. Under these circumstances, determining the right strategy for the further development of this form of business is the key to effective development of the agricultural sector, rural areas and the national economy as a whole. An effective policy aimed at overcoming the SF path dependence in Ukraine should study the rationale, reasons and motives that determine the involvement of the people in conducting this form of farming. This constitutes the main aim of the research.

Research method is analytical logic based on official national statistics underpinned by the comparative and correlation analysis. Based on a comparison of changes in the basic parameters characterizing the agricultural activity of household plots over time, structural changes in the agricultural sector of the country are identified. Applying the correlation analysis, the relationship between the trends and the main characteristics of agricultural activity of households in regions as well as socio-economic conditions of regions development is investigated. The correlation analysis is also used to identify the relationships between socio-economic dynamics in rural settlements and tendencies of household plots' development during 2008-2018.

The comparative analysis (2018/2008) shows that there is a reduction in the number of households in Ukraine in general, as well as of household plots in rural areas. The share of households keeping livestock, poultry and bees in rural and urban settlements is reduced; rural households are becoming more oriented on subsistence farming (by the proportion of land allocated for cultivation for their own needs), reducing the proportion of land used for commercial aim.

The results of correlation analysis show that for rural settlements the commercialization of households is closely linked to: the proportion of households without workers - the smaller this share is, the less commercialized the farms are (0.64); the coefficient of economic burden - the higher it is, the more intensive is the market activity of the households (0.74); the share of food expenditure in all expenditures - the higher it is, the more market oriented the household is (0.45); the average number of employees in the household - the higher it is, the less market-driven the farm is (-0.56); the share of active income in aggregate resources (the higher it is, the less market active is the household -0.69).

Results, obtained for personal peasant households (PPH) show that they are rather developed in regions where the average number of employees in one household is higher (0.55). It is interesting that as the unemployment rate increases, the number of PPHs will decline, meaning that this activity is not perceived as a proper alternative to a full day engagement (-0.54), but rather as part-time employment. In regions where the number of households without a single worker is higher, the total area occupied by PPHs will be higher (0.37), this is also true in the case of urban households (0.43). At the same time, the area of PPH is more directed to commodity production with increasing level of urbanization, as well as with increase in the number of households where there are no workers (0.46). In this case, these areas are formed through rented land (0.66 and 0.56, respectively). The number of PPHs correlates with the number of livestock, poultry and bee holdings (0.84). Moreover, with the increase in the number of such farms, PPH areas are allocated for the maintenance of a dwelling house (0.79) and conduct of personal peasant farming (0.53), but are eliminated from commodity production (-0.33) and rental relations (-0.46).

To sum up, one should emphasize that nowadays there is a decrease in the extension of households involved in agricultural production both for food self-sufficiency and for the production of products for sale in Ukraine. There are "natural" structural shifts in the sector, highlighted by Buchenrieder et al. (2009). At the same time, it is necessary to pay attention to the nature of these structural changes. In the context of the need to tackle the problem of subsistence farming, one should pay attention to another aspect of this problem - the lack of a strategy to support the establishment of a model of individual farming, which must counteract the risks of industrialized agri-production. After all, as the results of the analysis show, in the case of a revival of economic activity in rural areas 
(peripheral territories) as a result of the implementation of social policy measures, there will be a disappearance of the class of private small agricultural producers. This poses risks to food security, as it is these structures that make up the bulk of consumer basket products.

Keywords: subsistence farming, households, commercialization of agricultural producers, structural changes in agriculture, personal peasant farms, entrepreneurship.

Дата надходження до редакції: 29.01.2018 р. 